\title{
European Entrepreneurship Reinforcement Policies in Macro, Meso, and Micro Terms for the Post-COVID-19 Era
}

\author{
Dimos Chatzinikolaou ${ }^{1}$, Michail Demertzis ${ }^{2}$ \& Charis Vlados ${ }^{1,3}$ \\ ${ }^{1}$ Department of Economics, Democritus University of Thrace, Komotini, Greece \\ 2 Department of Law, Democritus University of Thrace, Komotini, Greece \\ ${ }^{3}$ School of Business, University of Nicosia, Nicosia, Cyprus \\ Correspondence: Michail Demertzis, Department of Law, Democritus University of Thrace, University Campus, 69100 \\ Komotini, Greece. E-mail: michaildemertzis@gmail.com
}

Received: February 28, 2021 Accepted: March 29, $2021 \quad$ Online Published: April 7, 2021

doi:10.5539/res.v13n2p39

URL: https://doi.org/10.5539/res.v13n2p39

\begin{abstract}
In today's unprecedented transformation in the global socio-economic system caused by the COVID-19 pandemic crisis and the escalating fourth industrial revolution, reinforcing innovative entrepreneurship appears a significant policy objective that can lead to overall socio-economic development. In this drastically changed context, entrepreneurship support policies seem that they need to be both conceptually and practically readjusted, simultaneously at the macro, meso, and micro levels. This paper investigates the case of public entrepreneurship policies in the European Union (EU), aiming to find specific patterns and suggest a new multilevel policy framework. Initially, the article offers a brief overview of the related trends created in the emerging post-COVID-19 era. Next, the "competitiveness web" perspective in terms of "macro-meso-micro" level synthesis is presented, considering that it can function as a theoretical framework for entrepreneurship reinforcement. Recent EU entrepreneurship support policy guidelines are then explored, emphasizing the latest trends and the development opportunities arising with the EU Recovery and Resilience Facility establishment to deal with the consequences of the current health and socio-economic crisis. Upon this basis, the paper concludes in a proposal for an integrated "macro-meso-micro" policy, placing at the epicenter the mechanism of the Institutes of Local Development and Innovation (ILDI). This policy aims to strengthen the spatially-located firms to reposition and readapt the "Stra.Tech.Man" potential they have and activate in their local business ecosystem (strategy-technology-management synthesis).
\end{abstract}

Keywords: Competitiveness web, Entrepreneurship support policy, EU Recovery and Resilience Facility (RRF), European integration, European public policy, ILDI, Macro-meso-micro, Post-COVID-19 era, Stra.Tech.Man approach

\section{Introduction}

In all the conditions and historical phases of capitalism, the firms' innovative action transforms the hosting socio-economic systems structurally (Schumpeter, 1942, 1954). Especially in the ongoing fourth industrial revolution and the emerging post-COVID-19 era, where digital transformation for all socio-economic actors seems imperative due to the progressive "blurring" between the physical and the digital world, innovative entrepreneurship acquires increasing significance as it constitutes the corridor for exiting the crisis (Roper \& Turner, 2020; Umar, Rizvi, \& Naqvi, 2021). Besides entrepreneurship, public policy also has a critical role, given that business innovation and regulatory efficiency are interdependent forces that can drive a socio-economic system towards greater sophistication, resilience, adaptability, and development (Carayannis et al., 2018; Ignatov, 2018; Uyarra \& Flanagan, 2010; Vlados et al., 2018b). It is not by chance that the European heads of states, considering the recent COVID-19 outbreak, call for a regulatory environment and state aid framework that favors innovation and facilitates entrepreneurs' full involvement (European Council, 2020).

Therefore, it seems significant to investigate how public policymakers can reshape an institutional environment that strengthens entrepreneurship and supports innovation. Interpreting how public policies for reinforcing entrepreneurship evolve could point to new elements for an integrated policy for the post-COVID-19 era (Terjesen, 2021; Zahra, 2021). To this end, a multilevel policy approach could be investigated, exploring macro-level aspects of the economy and society, the meso-level of localities and sectoral agglomerations, and the micro-level of firms and individuals (Baumannet et al., 2019; Peneder, 2017). In this context, the European Union's (EU) case can be an example of how public policies for entrepreneurship support are shaped and directed (Podkaminer, 2019). In the post-COVID-19 era and before reaching the "Europe 2020" development goals, Europe is forced to re-examine its focus (Grimaccia, 2020). The European 
socio-economic formation seems to be acquiring a repositioned content based on the results that countries achieve in health and socio-economic crisis management (Bozorgmehr et al., 2020; Meunier \& Mickus, 2020; Paché, 2020; Ruiu, 2020). Attracting investment, protecting employment, fostering innovation, and having an outward-oriented profile through integrated entrepreneurship and competitiveness policies seems to be of utmost significance (Chaves-Maza \& Martel, 2020; Ketels \& Porter, 2020).

Therefore, a research gap can be identified in terms of finding specific patterns or models on strengthening entrepreneurship to suggest integrated ways of stimulating the firms' innovation and resilience potential in the post-COVID-19 era, focusing especially on entrepreneurship enhancement policies in Europe. The research question that this study investigates is the following: At what levels (macro, meso, and micro) relevant public policies for supporting entrepreneurship are usually articulated? Could the EU case help us define respective patterns and reaffirm the need for a repositioned interventional perspective? Moreover, what implications are created concerning the structuration of more integrated policies in the post-COVID-19 era?

In this conceptual paper, a semi-systematic and critical review of the literature is conducted, aiming to explore the various kinds of applied policies to strengthen the resilience, innovativeness, and competitiveness of firms (Gilson \& Goldberg, 2015; Snyder, 2019). Also, according to basic principles of conceptual studies (Jaakkola, 2020), this article attempts a synthesis of the theoretical perspectives examining recent COVID-19 implications, entrepreneurship and related public policy issues, and interventions exercised at the overarching EU strategy level, having as primary goal to examine from a restructured perspective the articulation of various entrepreneurship support policies.

In section two, the emerging post-COVID-19 global environment and its implications for business are examined. In section three, public policy targets to reinforce entrepreneurship are conceptualized, followed by investigating a multileveled "competitiveness web" perspective that helps to define the macro, meso, and micro socio-economic development levels in different spatial systems. The recent European Union (EU) policy guidelines are explored in the fourth section, focusing on the entrepreneurship support case and contemporary trends in the post-COVID-19 era (the EU Recovery and Resilience Facility). In the fifth section, conclusions are drawn by emphasizing and counter-suggesting an integrated macro-meso-micro public policy for supporting entrepreneurship in today's Europe.

\section{The Emerging Post-COVID-19 Global Environment and the Implications for Entrepreneurship}

The global socio-economic system has entered an unprecedented crisis following the worldwide spread of COVID-19 since early 2020. According to António Guterres, Secretary-General of the United Nations, this situation of COVID-19 is bringing the world to a readjustment (United Nations, 2020). Humanity is facing unique challenges, where the most inferior socio-economic classes and localities are becoming more vulnerable. Guterres talks of the need for rapid worldwide coordinated intervention to deter the proliferation of similar health issues and to secure the world and these less-developed communities from socio-political extremism.

The COVID-19 pandemic crisis has sparked a decisive blow to the world's economy, as per the World Bank (2020), with the recession's size estimated to exceed all earlier recessions after the Second World War. In the same report, the World Bank forecasted a modest recovery for the global economy's GDP in 2021, following similar forecasts published by international organizations in the same period. Similarly, the International Monetary Fund (2020) refers to this COVID-19 socio-economic crisis as a situation and turbulence unlike any other, having expected a minor turnaround for the world economy in 2021. The International Labor Organization (2020) has suggested that four hundred million full-time jobs will have been lost in the second quarter of 2020 due to government-imposed lockdowns and social distancing. The World Trade Organization (Azevêdo, 2020) compared the present with the earlier global downturn of 2008-2009 and predicted that the current would be far worse in all indexes. Another issue that concerns the global community, as various international organizations argue (Food and Agriculture Organization, 2020; Organisation for Economic Co-operation and Development, 2020c), is the further reinforcement and spread of underdevelopment trends and socio-economic "pathogenies" across the world, with specific attention being paid to potential new exclusion types and development blockages and hysteresis. The industrial environment also appears to be transformed rapidly across the world since various economic sectors enter an aggressive recalibration and restructuration (International Civil Aviation Organization, 2020; International Energy Agency, 2020; World Health Organization, 2020).

The potential short-term recovery of the global economy is also an issue treated by policymakers and scholars from diverging perspectives. The OECD (2020b), for instance, forecasted a quasi-V-shaped rebound for global GDP in 2021, following a sharp fall in 2020. The European Central Bank (2020) predicted a less intensive rebound for the Eurozone, estimating that the real GDP will not record more than a $1.3 \%$ rise in 2021 and $1.4 \%$ in 2022 . In this context-and despite various scholars suggesting a V-shaped "revival" for the global economy - a swift turnaround from the crisis seems extremely difficult to be achieved (Beech, 2020; Gómez-Pineda, 2020; Gregory et al., 2020). Instead, in various socio-economic niches, an L-shaped turnaround appears more likely since a lack of flexibility, adaptability, and 
innovation could drive these less-developed areas to diminished competitiveness even though international trade would have begun to recover (Boschma, 2015; Vlados et al., 2019). Therefore, it becomes obvious that the world is entering gradually and inevitable restructuration, with most downside scenarios appearing increasingly probable to occur.

Concerning the impact of COVID-19 on business and entrepreneurship, in a policy research working paper series by the World Bank (Apedo-Amah et al., 2020), the short-term implications are addressed, focusing on the case of developing countries. The authors collected and analyzed data from fifty-one countries covering over 100,000 businesses and concluded that the COVID-19 crisis has severely hit most sectors, recording the most negative imprint on sales. Small firms are in greater financial danger, while all firms appear to rely on digital solutions to deal with the crisis implications. Kalemli-Ozcan et al. (2020) use a representative firm-level database in seventeen countries to measure SMEs' liquidity deficit during and after COVID-19. The authors find a significant rise of nine percentage points in SMEs' failure rate during this crisis, while they also name the most affected sectors, such as the accommodation and food services, arts, entertainment and recreation, education, and other services. This paper also puts forward a policy implication, noting that immediate business support measures can decrease business failures, although with a high fiscal cost. The suggested method for public policy is targeted interventions by avoiding resource misallocation and supporting firms that would fail one way or another.

In a report oriented towards supplying policy responses for SME development, OECD (2020a) notices that SMEs make up 50\% of employment across all OECD countries. The most worrying observation is that this percentage rises significantly in the sectors hit most by the crisis, approaching $75 \%$ on average across OECD countries and about $90 \%$ in Greece and Italy (Figure 1).

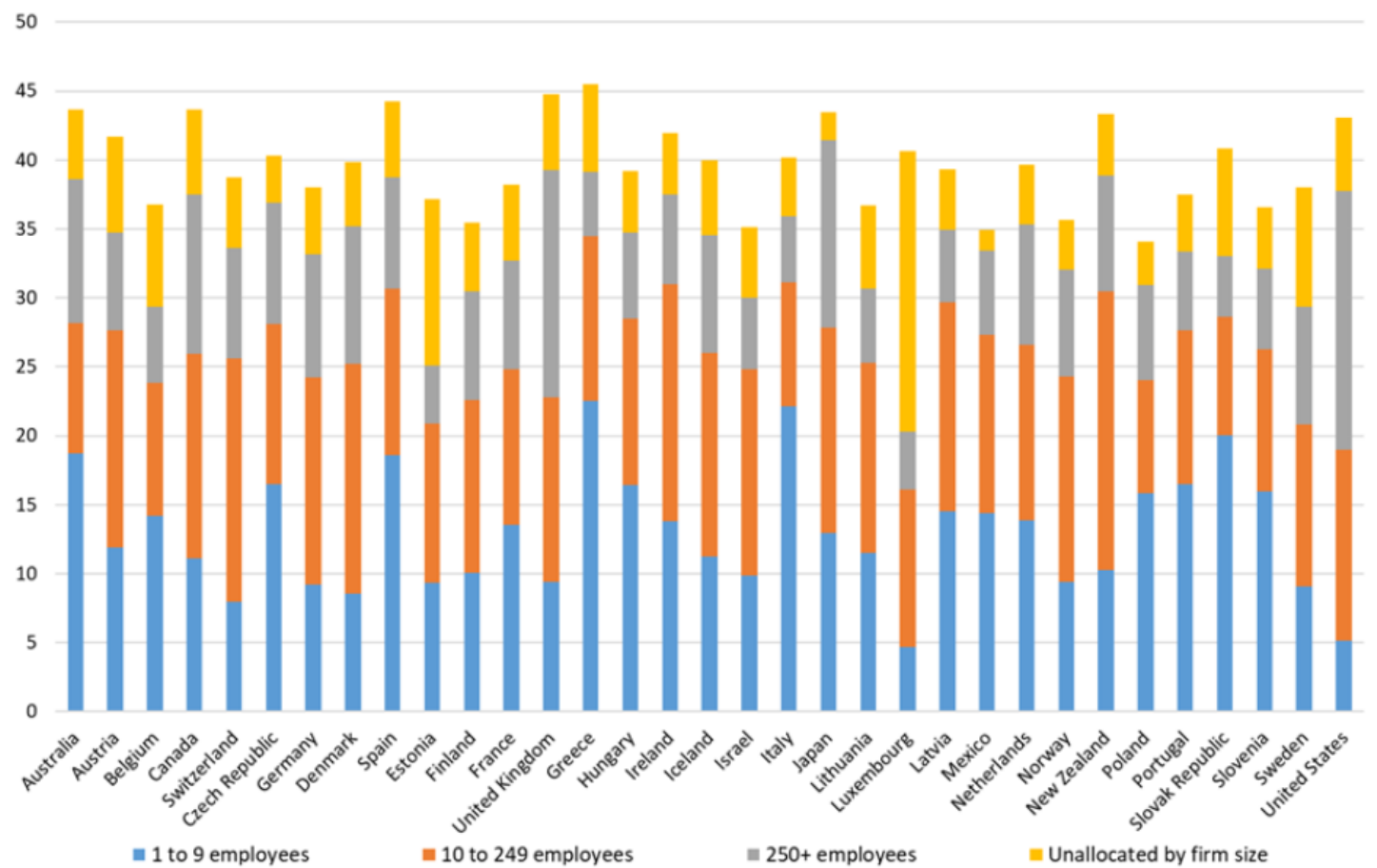

Figure 1. Smaller firms dominate in the most affected sectors. Share of total employment in the most adversely affected sectors by firm size (\%), as reproduced from OECD (2020a)

According to this report, the most affected sectors are transport, manufacturing, construction, wholesale and retail trade, air transport, accommodation and food services, real estate, professional services, and other personal services. The report continues by arguing that liquidity worries most entrepreneurs in these circumstances. To this end, although various governments have undertaken policy measures to address this liquidity gap and support SME survival, the most significant challenge is to support recovery for these firms in the post-COVID-19 era.

Overall, the newly emerging conditions of the post-COVID-19 era create for the entire global economy unprecedented challenges and pressures at all levels of today's socio-economic co-existence and co-evolution. At the macro-level of national and supranational policies (Dodds et al., 2020; Larionova \& Kirton, 2020), at the meso-level of economic sectors and various localities (Bragazzi, 2020; Gong et al., 2020), as in the micro-level of specific firms and 
entrepreneurship (Akpan et al., 2020; Anker, 2021). The following section addresses the problem of reinforcing these specific socio-economic levels by exploring various conceptual directions.

\section{Macro, Meso, and Micro Public Policy Analysis for Supporting Entrepreneurship and the Competitiveness Web}

Entrepreneurship is considered the primary development issue nowadays, especially in the arising post-COVID-19 era, where it can offer a sustainable route for exiting the crisis and setting up a long-term growth trajectory for the respective socio-economic systems and subsystems (Maritz et al., 2020; Shepherd, 2020). By reviewing recent definitions in the literature, a variety of interpretations can be found, each with a different outset and conclusion:

* Crumpton and Bird (2019, p. 171) mostly view entrepreneurship as innovation and opportunity: "Entrepreneurship means a creative or innovative approach to creating new value, typically in a commercial enterprise. It speaks to nontraditional methods of practice or discovering hidden opportunities to pursue."

* Bell (2020, p. xiii) attributes significance to overall economic development triggered by entrepreneurship: "Entrepreneurship is about more than economic development; it is also about human development. Entrepreneurship provides individuals the opportunity to guide their own destinies through work."

* The Information Resources Management Association (2019, p. 202) stresses the prerequisite individual effort and ethos: "Entrepreneurship refers to the activities an individual goes through from the development of an idea until the creation of an enterprise."

Although various scholars conceive contemporary entrepreneurship within a relatively abstract context, the evolutionary "theory of the firm" contributions argue that entrepreneurship is called upon to implement the specific process of innovation (Etemad, 2017; Malen, 2015). Entrepreneurship means economic and commercial exploitation of scientific knowledge, which translates into technology and inventions. The inventor is not the innovator (Berkun, 2007). The entrepreneur is the risk-taker who undertakes the effort to combine the always-scarce production factors for improving the firm's performance (to innovate). This entrepreneurial innovation-and from a neo-Schumpeterian perspective (Bodrožić \& Adler, 2018; Chatzinikolaou \& Vlados, 2019)_leads the entire socio-economic system towards positive development spirals. In this context, there are diverse theoretical perspectives in exploring the way entrepreneurship is reinforced in any socio-economic system. As a term, public policy for entrepreneurship evolves from more straightforward to complex conceptualizations and with the focus continually shifting (Elsner, 2017; Kurtz, 2018). In a typical definition, entrepreneurship support policy is identified as measures increasing entrepreneurial activity levels and creating an environment that encourages people to become entrepreneurs (Lundström \& Stevenson, 2005). Concerning the individual, public policy for entrepreneurship can turn the simple man into an entrepreneur by enriching the environment in which people grasp knowledge (Link, 2007).

A usual analytic expression in socio-economic sciences is the distinction between diverse levels. Although nowadays theoretical compartmentalization still exists between microeconomic and macroeconomic analysis — as Galbraith (1987) has noted in the past - this appears increasingly inadequate to embrace the whole spectrum of today's political economy. Modern approaches are progressively suggesting that all levels must be synthesized and thereby conceive all socio-economic phenomena from a unified perspective (Dopfer, 2011). At the policy articulation level, it could be argued that there are at least seven kinds of theoretical and practical approaches: macro, meso, micro, macro-meso, macro-micro, meso-micro, macro-meso-micro (Table 1).

Table 1. Various socio-economic policy levels in terms of reinforcing entrepreneurship. Definitions of macro, meso, micro policy levels

\begin{tabular}{lll}
\hline $\begin{array}{l}\text { Entrepreneurship } \\
\text { support policy } \\
\text { level }\end{array}$ & Suggested definition & Various related contributions \\
\hline Macro & $\begin{array}{l}\text { Macro policy refers to measures oriented towards } \\
\text { improving the aggregate economic and business } \\
\text { environment, expressed in national, international, } \\
\text { or supranational terms. }\end{array}$ & $\begin{array}{l}\text { (Ahluwalia, 2015; Hartwell, 2014; } \\
\text { Timmer, 2000) }\end{array}$ \\
\hline Meso & $\begin{array}{ll}\text { Meso policy is about strengthening specific } \\
\text { sectoral, industrial, business cluster, and business } \\
\text { ecosystem environments, aiming to reinforce them } \\
\text { selectively. }\end{array}$ & $\begin{array}{l}\text { (Alanguren et al., 2018; Meyer-Stamer, 2005; } \\
\text { Parr, 1999; Sedelmeier, 2002) }\end{array}$ \\
\hline Micro & $\begin{array}{l}\text { Micro policy refers to measures targeting the } \\
\text { short-term reinforcement of specific firms, } \\
\text { favoring the usage of advising, training, and }\end{array}$ & $\begin{array}{l}\text { (Bianchi, 2000; Fotopoulos \& } \\
\text { Storey, 2019; OECD, 2007) }\end{array}$ \\
\hline
\end{tabular}




\begin{tabular}{|c|c|c|}
\hline & consulting instruments. & \\
\hline Macro-meso & $\begin{array}{l}\text { Macro-meso policy is primarily a traditional } \\
\text { regional growth instrument, usually articulated in } \\
\text { top-down terms and executed nationwide. }\end{array}$ & $\begin{array}{l}\text { (Falck et al., 2011; } \\
\text { Godlewska-Majkowska et al., } \\
\text { 2016; Hemphill \& White, 2013; } \\
\text { OECD, 2009; Vlados \& } \\
\text { Chatzinikolaou, 2020a) }\end{array}$ \\
\hline Macro-micro & $\begin{array}{l}\text { Macro-micro policy is primarily a conventional } \\
\text { practice, suggesting that macroeconomic growth } \\
\text { can lead to direct business development. }\end{array}$ & $\begin{array}{l}\text { (Basu \& Mallick, 2008; Islam et } \\
\text { al., 1992; Sowell, 2012; Watkins, } \\
\text { 2014) }\end{array}$ \\
\hline Meso-micro & $\begin{array}{l}\text { Meso-micro policy concerns suggested and } \\
\text { implemented supporting measures via intermediate } \\
\text { organizations, having the aim to link all actors that } \\
\text { could stimulate specific entrepreneurial structures } \\
\text { at various localities and sectoral orientations. }\end{array}$ & $\begin{array}{l}\text { (Falck et al., 2010; Menu, 2012; } \\
\text { Porter, 1990; Rinkinen, 2016; } \\
\text { Vlados \& Chatzinikolaou, 2020b) }\end{array}$ \\
\hline Macro-meso-micro & $\begin{array}{l}\text { Macro-meso-micro policy is about an integrated } \\
\text { and unified conceptualization and practice-in } \\
\text { macro, meso, and micro levels } \\
\text { simultaneously-directed towards achieving } \\
\text { long-term socio-economic development goals in } \\
\text { national, international, and supranational terms. }\end{array}$ & $\begin{array}{l}\text { (Dovers, 1995; Howlett, 2009; } \\
\text { Mirzanti et al., 2015; Virtanen \& } \\
\text { Uusikylä, 2004; Vlados \& } \\
\text { Katimertzopoulos, 2018; Zezza \& } \\
\text { Llambí, 2002) }\end{array}$ \\
\hline
\end{tabular}

According to Audretsch and Beckmann (2007), entrepreneurship support policy is a multilevel system that enables the creation and commercialization of innovative ideas. From these definitions supplied in Table 1, the multilevel framework's dynamic character can be discerned, emphasizing the linking and "intermediating" role of the meso-level. The meso-level gives a dynamic and evolving socio-economic dimension to targeted economic policies (Lee, 2011; Mann, 2011). However, in the "macro-meso-micro" analytical direction, a novel and synthesizing approach is born. According to Vlados (2019b), the socio-economic system is a multilevel and evolutionary synthesis of subsystems that interact dynamically—a "competitiveness web" (Figure 2).

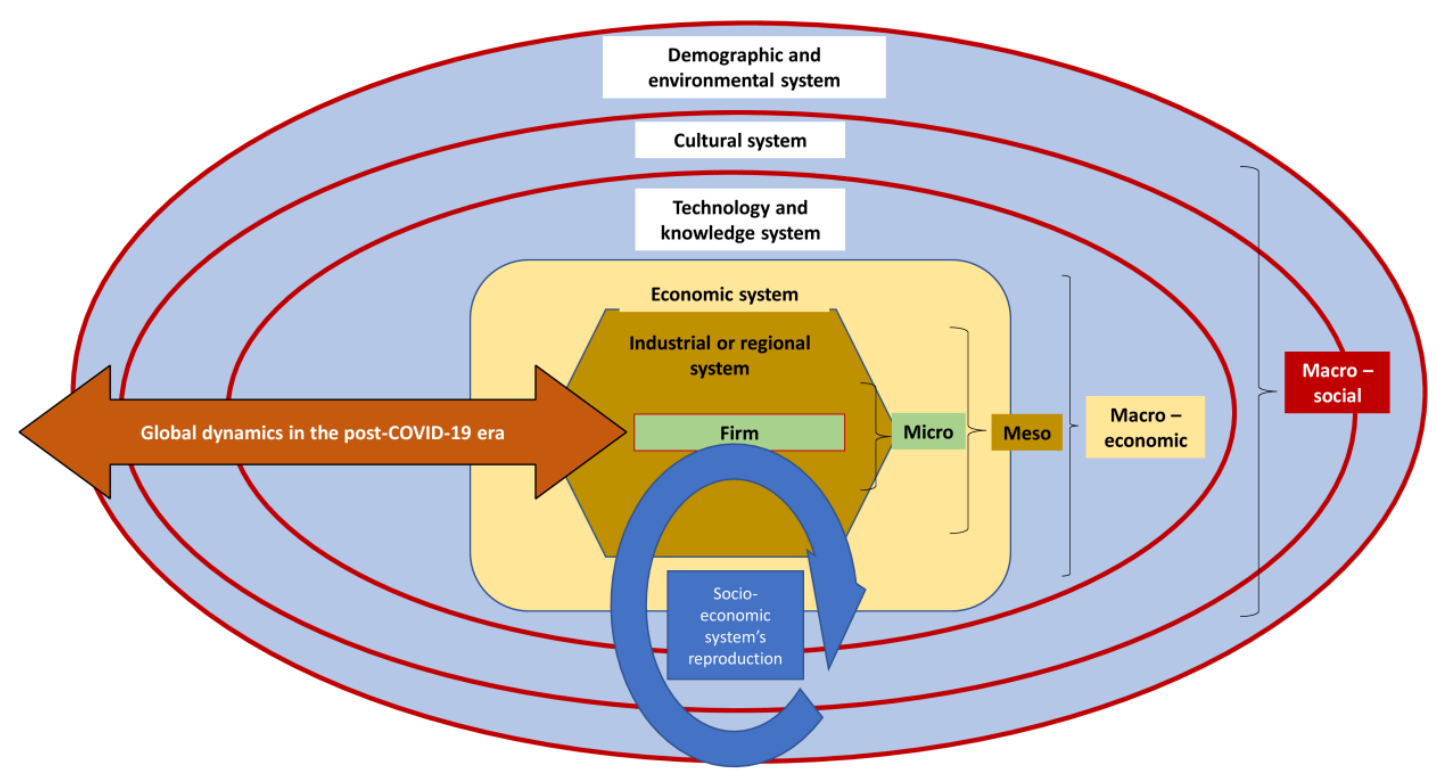

Figure 2. The multilevel socio-economic system in the form of the competitiveness web, based on Vlados (2019b)

All spatial levels and socio-economic subsystems are structurally correlated in this "web" of interdependencies, having in front of them nowadays the challenge of effectively adapting into the post-COVID-19 era. Any change in the macro, the meso, or the micro transforms in systemic terms all other levels. By considering that the competitiveness web is an attempt at conceiving the socio-economic system in its entirety, including the interactions among its systemic elements, it can become a tool for analyzing different economic policies, such as public policies for stimulating entrepreneurship. Based on the dynamic formation offered by this reasoning, entrepreneurship support policies can be distinguished in those that affect: 
1. the various social factors related to the system's development prospects, such as the technological and cognitive dynamics and the cultural and demographic-environmental dynamics (macro-social),

2. the dynamics of the economy, as determined by the increase or decrease in aggregate economic performances (macro-economic),

3. the dynamics of localities and other spatial aggregations (industries and clusters) between firms (meso)

4. the evolutionary dynamics of the firm (micro).

This unifying theoretical scheme can be applied at any spatial level (local, national, or supranational). From this systemic web perspective, competitiveness analysis enters a repositioned conceptual framework in the post-COVID-19 era. It is assumed that all spatial socio-economic subsystems interact and reproduce their survival potential in a dynamic and multilevel way (macro-meso-micro). This "macro-meso-micro" perspective of the competitiveness web can also be useful for creating integrated public policies to strengthen entrepreneurship as it helps to conceive at what level various policy programs are targeted. The following section examines the case of relevant policy guidelines put forth by the European Union.

\section{The EU Policy Framework Case for Entrepreneurship Support: Contemporary Trends and the Recovery and Resilience Facility (RRF)}

After The European Union (EU), although "supranational," is an integrated system under construction and a distinct legal entity — sui generis (Binder \& Hofbauer, 2017; Phelan, 2012). Since the signing of the Maastricht Treaty and the single market implementation, it has become increasingly significant to recognize the European Community (now the European Union) as a legal order that consists of an organized and structured system of legal rules, with respective sources, institutions, and practical procedures to interpret and enforce these rules (Kochenov, 2008; Reimann \& Zimmermann, 2019). The EU institutions resemble respective institutions and norms found in traditional international organizations. However, according to De Cruz (1999), a comparative law approach can highlight the EU institutions' specificity. First, the institutions do not correspond to the classic form of separation of powers since, for example, the European Parliament (formerly the Common Assembly) is primarily an advisory body with no competence to influence the legislation's content. Second, another unique feature of the institutions is that they are involved - and usually exercise a significant degree of regulatory control - in issues that have traditionally been within sovereign states' exclusive competence. Finally, it should be stressed that, unlike other international institutions, they were created with the primary goal of European political integration and, therefore, even the European Court of Justice takes decisions with European integration in mind. Thus, the EU law has separate power and will bypass local law where the latter is not directly applicable.

Although the "problem of supranationality" creates political and legal dilemmas within the methods and modus operandi, the EU's effort in promoting economic development and worldwide democracy and human rights is increasingly noticed (Bulmer \& Joseph, 2016; Cross, 2007). The EU tries to promote cooperation and sub-regional integration outside its borders, which requires political stability, socio-economic development and fighting poverty and social exclusions (Decreux \& Guérin, 2001; Draper, 2012; Jetschke \& Murray, 2012). However, stability in a regional integration formation such as the EU requires the ability to set up and reinforce three main dynamics: a continuous strengthening in competencies, a deepening level of integration, and an increasing number of regional participants (Pelkmans, 1993). From a historical perspective, the EU has always been committed to one — or two at most aims - but has never been able to implement all three simultaneously and effectively. Yvars (2010) argues that such simultaneous action goes beyond any regional integration possibilities.

In this context, the EU creates and implements various policies geared towards sustainable socio-economic development in the member-states. These overarching policy directions set agendas on various issues, mostly from a multilevel perspective. In recent years, the EU has been increasingly giving weight to promoting entrepreneurship and business development by promoting at least four converging orientations - various of them were developed actively during the past years. The corresponding EU framework is primarily directed by its industrial policy guidelines, implemented as targeted programs and action plans focused on strengthening the entrepreneurial environment and specific skills at the micro-level. The Small Business Act (SBA), the Entrepreneurship 2020 Action Plan (EAP), and the Research and Innovation Strategy for Smart Specialization (RIS3), based on the Smart Specialization Strategies (S3s) from the EU's 2014-2020 cohesion policy, are significant projects in this direction, focusing on overlapping critical points (Table 2). 
Table 2. Summary of the main points and goals of fundamental EU policies that directly or indirectly aim to foster and support entrepreneurship. Sources: European Commission (2012, 2013, 2014, 2017, 2017), Council of the European Union (2017)

\begin{tabular}{|c|c|}
\hline $\begin{array}{l}\text { EU' } \\
\text { poli }\end{array}$ & $\begin{array}{l}\text { Funding, modernization through digitization, and workforce training for businesses-Skills development in } \\
\text { specific industries - Trade policy to ensure fair competition in the areas of space, defense, and steel-Small } \\
\text { and medium-sized enterprises (SMEs) support-Stimulation of innovation-Promotion of trade, } \\
\text { environmental goals, digitization, and facilitation of easy access to raw materials-Take advantage of modern } \\
\text { technologies and the EU's single market-Attract investment }\end{array}$ \\
\hline & $\begin{array}{l}\text { Education and training for entrepreneurship-Efficient bankruptcy procedures and a second chance for } \\
\text { entrepreneurs-"Think Small First": Institutional and regulatory framework for SME policymaking-Support } \\
\text { services for SMEs and public procurement-Supporting SMEs so that they can take advantage of } \\
\text { Euro-Mediterranean networks and partnerships-Internationalization of SMEs-Improve the approach to } \\
\text { entrepreneurship in Europe-Simplify the regulatory framework for SMEs-Remove the remaining obstacles } \\
\text { to SME development (access to finance and markets) }\end{array}$ \\
\hline $\begin{array}{l}\text { neurship } \\
\text { on Plan }\end{array}$ & $\begin{array}{l}\text { Entrepreneurial education and professional training-Access to finance-Strengthening new businesses in } \\
\text { crucial phases of their lifecycle and helping them grow-Unleashing new business opportunities in the digital } \\
\text { age-Second chances for honest bankrupts-Regulatory burden (clearer and more straightforward } \\
\text { rules)—Unleash Europe's business dynamics—-Strengthening entrepreneurial education and supporting } \\
\text { business creation }\end{array}$ \\
\hline $\begin{array}{l}\text { Research and } \\
\text { Innovation Strategy } \\
\text { for Smart } \\
\text { Specialization } \\
\text { (RIS3) }\end{array}$ & $\begin{array}{l}\text { Revealing what a country or region does best in terms of R\&D and innovation and prioritizing critical } \\
\text { decisions-Materializing structural changes in the EU industry with a decentralized logic-Encourage EU } \\
\text { regions to turn their needs, strengths, and competitive advantages into marketable goods and } \\
\text { services-Reorganize traditional sectors through the shift to high value-adding activities, new markets, or } \\
\text { value chains-Modernization of existing businesses through the adoption and diffusion of modern } \\
\text { technologies-Differentiation through technology and the development of new activities via innovations }\end{array}$ \\
\hline
\end{tabular}

There seems to be a multilevel conception geared towards reinforcing all socio-economic activity in the relevant EU policy guidelines. More general lines are set in the overarching industrial policy, which are further specialized in the other targeted programs towards entrepreneurship support. Interestingly, in industrial policy-which must be "by nature" multileveled since it targets the macro-meso-micro levels simultaneously (Vlados \& Chatzinikolaou, 2020c; Warwick, 2013) - directions appear that focus on supporting specific firms through training for modernization and digitization, which also are significant aspects for the post-COVID-19 era (Bonilla-Molina, 2020; Winarsih et al., 2021). The SBA and the EAP primarily include macro-targeted measures oriented towards institutionalizing an innovative business environment without intense intervention and "legal frictions," focusing also on aspects related to entrepreneurship education and the creation of innovative businesses. RIS3 appears to specialize the industrial policy directions in specific localities from a prevailing meso-targeting, stressing the need to reorganize specific sectors. It is worth noting that the "smart specialization" approach that led to RIS3 was based on the idea of identifying strategic areas for research and innovation interventions on a "place-based" orientation and practice (Foray, 2018; Foray et al., 2009).

It should also be pointed out that the EU at the central policy level seemed somehow ready to deal with the emerging wave of the fourth industrial revolution and the post-COVID-19 era (Schäfer, 2018; Weresa, 2019). However, it should be noted that the idiosyncratic politico-economic and legal nature and not fully integrated socio-economic structure of this supranational entity currently prevents a single, common economic policy, and, therefore, the impact of the EU policies naturally varies from one country to another (Andreou et al., 2017; Autio, 2016; Muller et al., 2015). Moreover, the basic structure of the economic policy regime in the Eurozone is characterized by duality since it is formed by a monetary policy planned centrally at the EU level and by a fiscal policy shaped by the national governments (Stockhammer, 2017), which do not always seem to consider the related European criteria as binding (Schalck, 2012). Consequently, the EU policies that directly or indirectly focus on fostering and supporting entrepreneurship do not always look alike, nor do they lead to the same results across European countries.

Nowadays, amid the pandemic crisis of COVID-19, the European Council agreed on July 21, 2020, to put forth the "Next Generation EU (NGEU)," a massive recovery fund of 750 billion euros to support the member-states (European Council, 2020). The "NGEU" is tied to the 2021-2027 next EU Multiannual Financial Framework, spanning over the years 2021-2023 (Crum, 2020). The breakthrough in the EU policy design that the NGEU achieved was that for the first time in its history, the EU would issue European sovereign bonds for distributing grants and loans to the member states by generating own resources with direct taxation - a practice considered a significant step towards fiscal integration in the EU (Cabral, 2021; Porte \& Jensen, 2021). More specifically, member states agreed to submit national Recovery and 
Resilience Plans (RRP) to receive support from the Fund that would outline how they will use these investments to contribute to the green and digital goals set by the European Commission. Thirty-seven percent of investment should be channeled to green actions and twenty-one percent to digital actions, following the EU climate neutrality goal of 2050 (Dupont et al., 2020; Karlsson \& Silander, 2020).

In conclusion, the political guidelines for supporting entrepreneurship in the EU have mostly scattered "macro, meso, and micro" elements that do not follow an integrated perspective as in the competitiveness web approach. Creating and promoting a unified "macro-meso-micro" framework also seems to determine the RRF's success. Member states now need to further coordinate their economic policies, oriented towards entrepreneurship support that can decisively contribute to the sustainable green and digital goals. In the concluding section, a policy aligned with the present-day challenges in Europe is suggested.

\section{Concluding Remarks and Proposals: The ILDI and the "Macro-Meso-Micro" Entrepreneurship Enhancement Policy Mechanism for the EU in the Post-COVID-19 Era}

This conceptual paper analyzed various policy schemes for supporting and strengthening innovative entrepreneurship and safeguard the resilience and viability of firms and socio-economic systems in the emerging post-COVID-19 era. It tried to examine at what levels relevant public policies that strengthen entrepreneurship are articulated, focusing on the European Union's case. It studied the arising context of the COVID-19 pandemic crisis and the fourth industrial revolution's acceleration, emphasizing current entrepreneurship implications. After defining the diverse macro, meso, and micro levels and their combinations, it highlighted the increasing significance of a unified conceptualization in macro-meso-micro policy alignment. The main research implication is that EU relevant policy guidelines appear to have scattered macro, meso, and micro constituents that, if further unified and in terms of the RRF, can also be the basis for better addressing the current crisis and deriving global restructuring. Specifically, our study concludes that this challenge could be addressed by a specific policy mechanism capable of diagnosing the Stra.Tech.Man physiology (strategy-technology-management synthesis) of the spatially-located firms. A readjusted policy to enhance local entrepreneurship, resilience, and competitiveness can facilitate the adaptation of local socio-economic systems - especially the less developed, adaptable, and innovative ones - to the emerging post-COVID-19 restructured global environment.

In this context, it seems increasingly necessary for all European regions - typically the least developed - to obtain or keep their distinct competitive advantages (Henry \& Smith, 2021; Mason \& Hruskova, 2021). A policy mechanism has been suggested in the recent past, which can be a more cohesive framework for the post-recovery-fund era in the EU, contributing specifically to local and regional development. Understanding the significance of the macro-meso-micro levels of policy for less-developed European regions, Vlados and Chatzinikolaou (2019a) have suggested the policy mechanism of the "Institutes of Local Development and Innovation" (Figure 3).

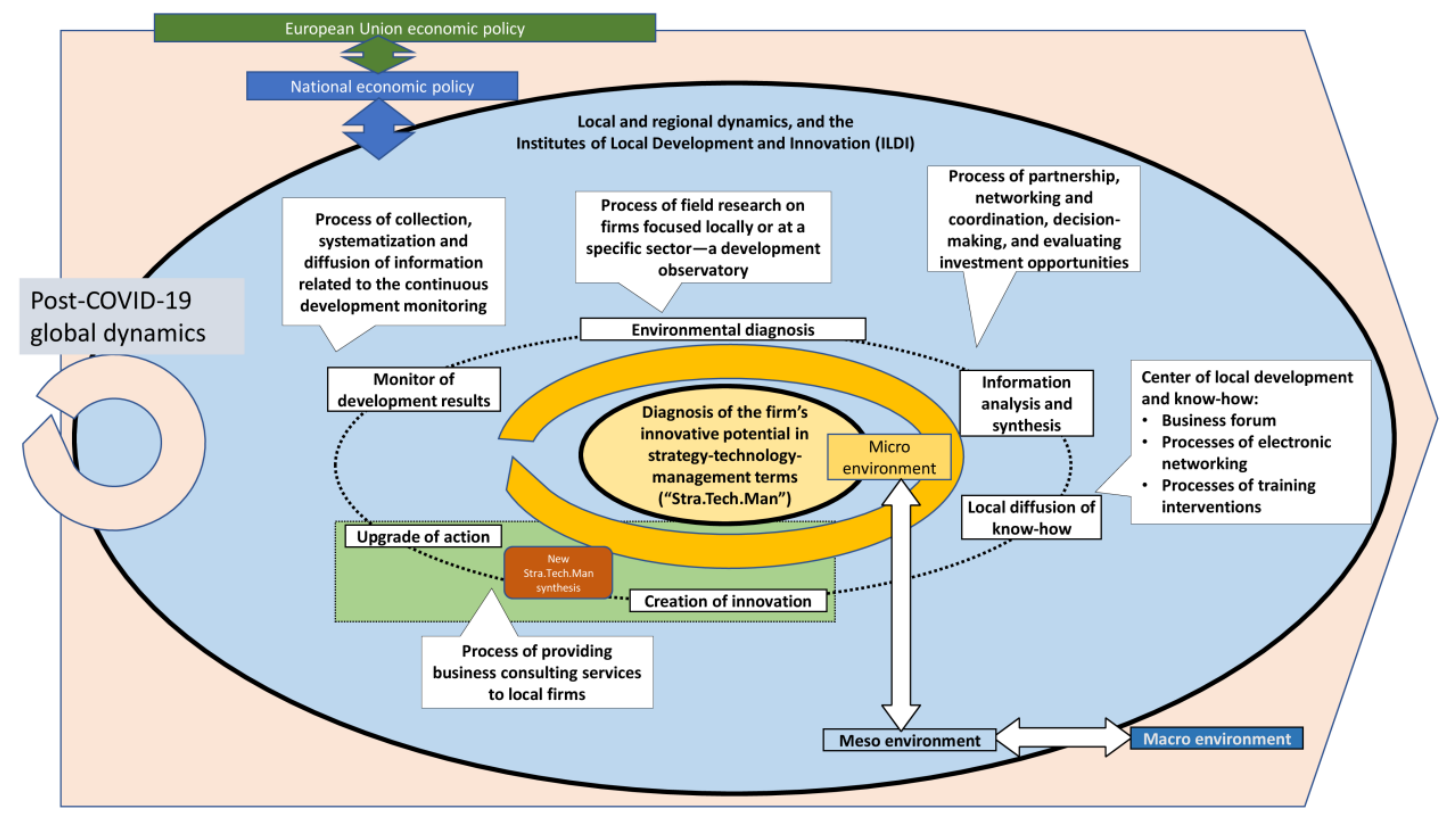

Figure 3. The complete macro-meso-micro policy mechanism of the Institutes of Local Development and Innovation (ILDI), adjusted from Vlados and Chatzinikolaou (2019a) 
In this policy recommendation, firms are conceived as "socio-economic organisms" who think and act-they have a specific business rationale or "physiology"-according to how they synthesize the spheres of strategy, technology, and management (Vlados, 2004, 2019a). Each sphere corresponds to a series of questions that lead to a preliminary diagnosis of the firm's innovation potential in terms of "Stra.Tech.Man" (strategy-technology-management synthesis). The firm's strategy corresponds to where the organization is and where it desires to go in the foreseeable future, technology concerns how it creates and uses its knowledge, and management the methods it implements to handle its always-scarce available resources. The suggested macro-meso-micro policy mechanism of the ILDI is built around this diagnosis as a one-stop-shop calibrated towards regional entrepreneurship development and innovation (Pike et al., 2012; Scholta et al., 2019).

The ILDI could follow a six-step method by initially building a system of environment diagnosis and creating the conditions to process specific field research on firms focused locally or at a specific sector-to construct a "development observatory." The next step refers to analyzing and synthesizing available information, moving forward with seeking regional partnership, networking and coordination, decision-making, and evaluating investment opportunities. The third step concerns diffusing knowledge locally by setting up digital business forums and general (cross-industry) training interventions. The following two steps of this policy cycle refer to firm-specific consulting by the institution's experts, aiming to foster innovation and upgrade the firm's "Stra.Tech.Man." The last step is about keeping momentum by publishing reports concerning the synthesizing development results achieved over the past cycle. Conclusively, such a mechanism may stimulate the innovative potential of a whole country that implements it — and so the EU—and it is not by chance that regional and local development policies are a priority in the post-COVID-19 era for a growing number of countries (Epifanova et al., 2020; Rodríguez-Cohard et al., 2020).

In this direction, various approaches related to the "helix theory" have been developed, suggesting a method of reinforcing innovation in different spatial levels (Rodrigues \& Melo, 2012; Sá et al., 2018). The three fundamental dimensions synthesized in the helix theory are the industry, the academia, and the government, which can also function within the framework of different spatial-based policies to reinforce specific business ecosystems (Metcalfe, 2010; Nakwa et al., 2012). The ILDI approach could function as an intermediate organization in this helix theory scheme (Figure 4).

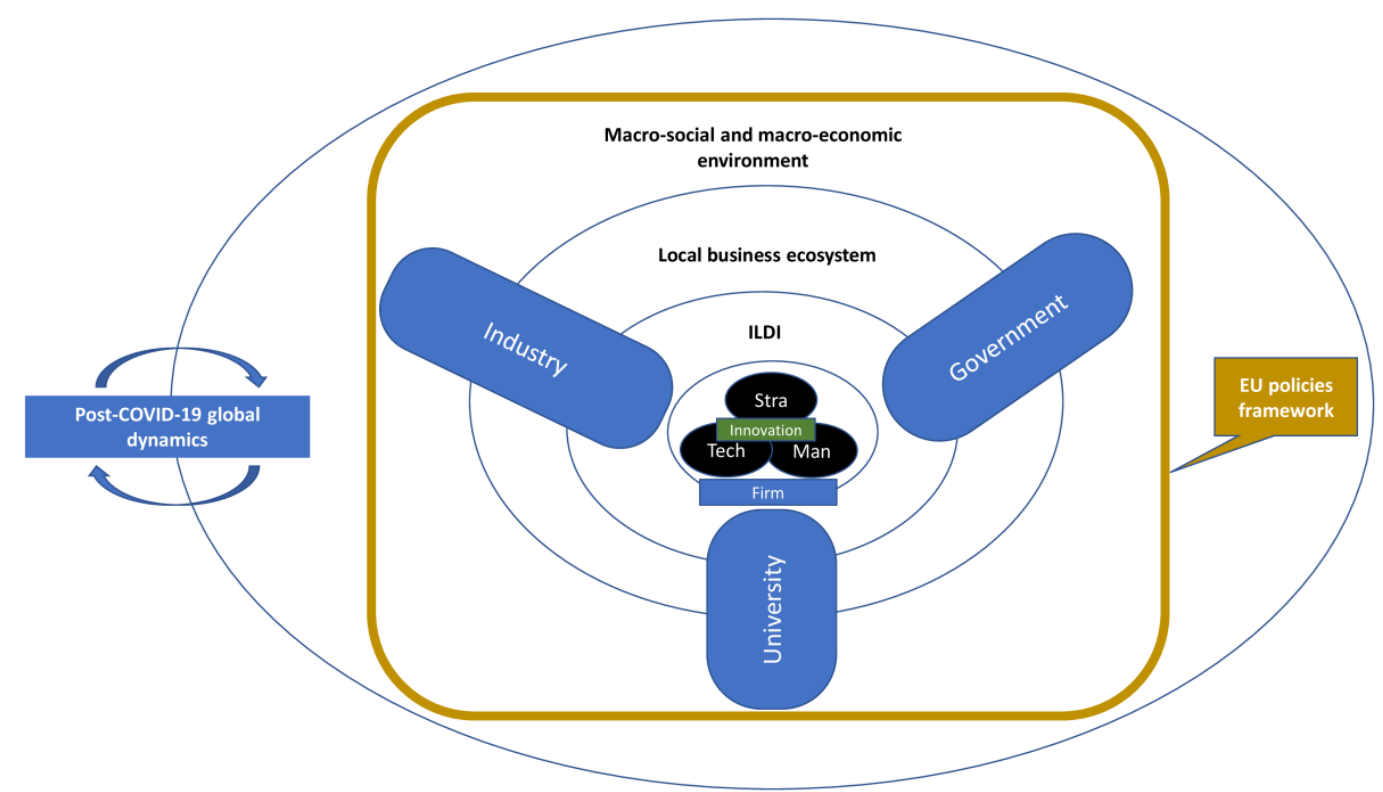

Figure 4. The Institutes of Local Development and Innovation (ILDI) as an intermediate organization from the perspective of helix theory, as adjusted from Vlados and Chatzinikolaou (2019b)

According to Vlados and Chatzinikolaou (2019b), firms are the socio-economic organizations that lie at the center of the business ecosystem, while the ways they synthesize their spheres of strategy, technology, and management decide the entire system's evolutionary prospects. The ILDI can be an intermediate organization that draws and spreads knowledge and skills from the three helices within the current dynamics of globalization in the post-COVID-19 era. Therefore, the ILDI is a policy mechanism that could synthesize at the European level the "macro-meso-micro" environment from a unified perspective. In this sense, a practical integrated policy linking the EU's overall intervention 
for the post-COVID-19 era with different national policies could be articulated based on the agreed Recovery and Resilience Facility. These national policies could be further specialized in various regional and industrial plans and actions, using the ILDI as a synthesis mechanism for all actors that can potentially stimulate local development (Vlados, Deniozos, \& Chatzinikolaou, 2018). These local actors are universities and other educational and training institutions, startup financing mechanisms, chambers of commerce, national organizations for employment, banks, cooperatives, and other related institutions (Figure 5).

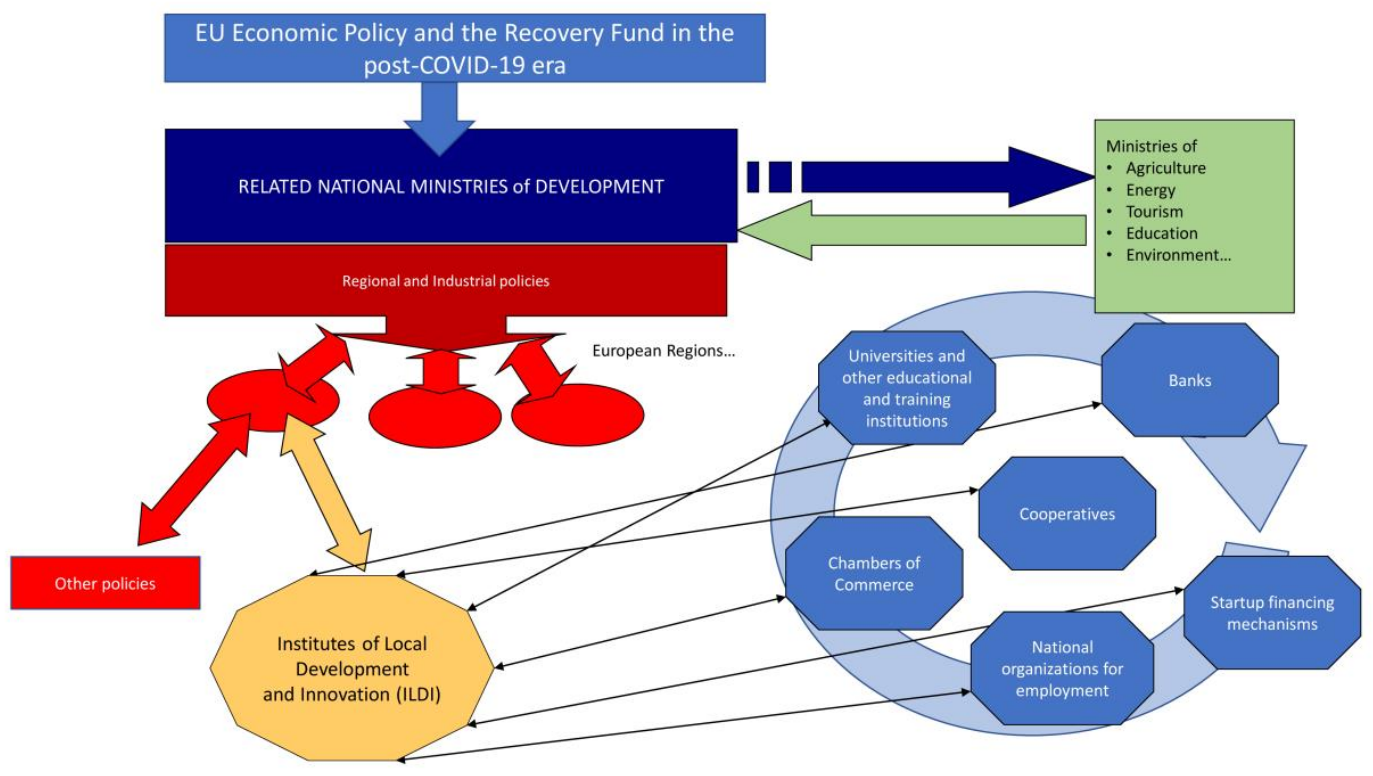

Figure 5. The macro-meso-micro policy mechanism of the Institutes of Local Development and Innovation (ILDI) for various regional and industrial plans in Europe in the post-COVID-19 era, as adjusted from Vlados et al. (2018a)

In this way, the ILDI can be a bridge to the EU policy articulation with other national policies in Europe, focusing on the locality and the various economic sectors (meso) and having as a final goal the strengthening of every firm's internal potential exerted in this specific space (micro). In this unique environment that rises nowadays, it will be of utmost significance how all firms - at any spatial or sectoral level-succeed to reposition themselves in terms of strategy-technology-management by reproducing a new "Stra.Tech.Man" innovative synthesis to adapt in the post-COVID-19 era. This suggested mechanism could offer solutions for new questions and challenges arising for all socio-economic systems within the EU and, in particular:

A. Help the common European policy focus on various localities and economic sectors, emphasizing the specific needs of the most affected and vulnerable cases.

B. Aid specific firms in a wide variety of sectoral and local foci to strengthen their internal potential by upgrading their strategic, technological, and managerial capabilities and thus improving their resilience and sustainability.

C. Enable various socio-economic systems to heal the wounds left by the COVID-19 crisis at all levels of their socio-economic web, enhancing their ability to set a new sustainable development trajectory in the post-COVID-19 era.

\section{Acknowledgments}

We warmly thank Dr. Andreas Andrikopoulos, Associate Professor at the Department of Business Administration of the University of the Aegean, who offered valuable comments on this manuscript's last version.

\section{References}

Ahluwalia, M. S. (2015). Role of economists in policy-making (No. 144; WIDER Working Paper Series). World Institute for Development Economic Research (UNU-WIDER). https://doi.org/10.35188/UNU-WIDER/2015/033-1

Akpan, I. J., Soopramanien, D., \& Kwak, D.-H. (2020). Cutting-edge technologies for small business and innovation in the era of COVID-19 global health pandemic. Journal of Small Business \& Entrepreneurship, 1-11. https://doi.org/10.1080/08276331.2020.1799294 
Andreou, A., Andrikopoulos, A., \& Nastopoulos, C. (2017). Chapter 1 - Debt markets, financial crises, and public finance in the Eurozone: Action, structure, and experience in Greece. In F. Economou, K. Gavriilidis, G. N. Gregoriou, \& V. Kallinterakis (Eds.), Handbook of investors' behavior during financial crises (pp. 3-28). https://doi.org/10.1016/B978-0-12-811252-6.00001-3

Anker, T. B. (2021). At the boundary: Post-COVID agenda for business and management research in Europe and beyond. European Management Journal. https://doi.org/10.1016/j.emj.2021.01.003

Apedo-Amah, M. C., Avdiu, B., Cirera, X., da Cruz, M. J. V., Davies, E., Grover, A., ... Thu Tran T. (2020). Unmasking the impact of COVID-19 on businesses: Firm level evidence from across the world (Policy Research Working Paper No. 9434; Finance, Competitiveness and Innovation Global Practice). World Bank. https://doi.org/10.1596/1813-9450-9434

Aranguren, M. J., Magro, E., \& Wilson, J. R. (2017). Regional competitiveness policy evaluation as a transformative process: From theory to practice. Environment and Planning C: Politics and Space, 35(4), 703-720. https://doi.org/10.1177/0263774X16662469

Audretsch, D. B., \& Beckmann, I. A. (2007). From small business to entrepreneurship policy. In D. B. Audretsch, I. Grilo, \& A. Thurik (Eds.), Handbook of research on entrepreneurship policy (pp. 36-53). Cheltenham: Edward Elgar. https://doi.org/10.4337/9781847206794

Autio, E. (2016). Entrepreneurship support in Europe: Trends and challenges for EU policy [Report prepared for EU DG Growth]. London: Imperial College Business School.

Azevêdo, D. G. (2020). Trade set to plunge as Covid-19 pandemic upends global economy. WTO Trade Forecast Press Conference, 8. Retrieved from https://www.wto.org/english/news_e/pres20_e/pr855_e.htm

Basu, S., \& Mallick, S. (2008). When does growth trickle down to the poor? The Indian case. Cambridge Journal of Economics, 32(3), 461-477. https://doi.org/10.1093/cje/bem053

Baumann, C., Cherry, M., \& Chu, W. (2019). Competitive Productivity (CP) at macro-meso-micro levels. Cross Cultural \& Strategic Management, 26(2), 118-144. https://doi.org/10.1108/CCSM-08-2018-0118

Beech, P. (2020, May 19). Z, V or "Nike swoosh" - what shape will the COVID-19 recession take? World Economic Forum. Retrieved from https://www.weforum.org/agenda/2020/05/z-u-or-nike-swoosh-what-shape-will-our-covid-19-recovery-take/

Bell, D. (2020). Aid donor collaboration, organizational behavior, and aid flow predictability: Not your father's bureaucracy. Lexington Books. Retrieved from http://public.eblib.com/choice/PublicFullRecord.aspx?p=6235833

Berkun, S. (2007). The myths of innovation. Cambridge: O'Reilly.

Bianchi, P. (2000). Policies for Small and Medium-Sized Enterprises (SMEs). In W. Elsner \& J. Groenewegen (Eds.), Industrial policies after 2000 (pp. 321-343). https://doi.org/10.1007/978-94-011-3996-0_11

Binder, C., \& Hofbauer, J. A. (2017). The perception of the EU legal order in international law: An in- and outside view. In M. Bungenberg, M. Krajewski, C. Tams, J. P. Terhechte, \& A. R. Ziegler (Eds.), European yearbook of international economic law 2017 (pp. 139-203). https://doi.org/10.1007/978-3-319-58832-2_6

Bodrožić, Z., \& Adler, P. S. (2018). The evolution of management models: A neo-schumpeterian theory. Administrative Science Quarterly, 63(1), 85-129. https://doi.org/10.1177/0001839217704811

Bonilla-Molina, L. (2020). Covid-19 on Route of the Fourth Industrial Revolution. Postdigital Science and Education, 2(3), 562-568. https://doi.org/10.1007/s42438-020-00179-4

Boschma, R. (2015). Towards an Evolutionary Perspective on Regional Resilience. Regional Studies, 49(5), 733-751. https://doi.org/10.1080/00343404.2014.959481

Bozorgmehr, K., Saint, V., Kaasch, A., Stuckler, D., \& Kentikelenis, A. (2020). COVID and the convergence of three crises in Europe. The Lancet Public Health, 5(5), e247-e248. https://doi.org/10.1016/S2468-2667(20)30078-5

Bragazzi, N. L. (2020). Digital Technologies-Enabled Smart Manufacturing and Industry 4.0 in the Post-COVID-19 Era: Lessons Learnt from a Pandemic. International Journal of Environmental Research and Public Health, 17(13), 4785. https://doi.org/10.3390/ijerph17134785

Bulmer, S., \& Joseph, J. (2016). European integration in crisis? Of supranational integration, hegemonic projects and domestic politics. European Journal of International Relations, 22(4), 725-748. https://doi.org/10.1177/1354066115612558

Cabral, N. da C. (2021). Borrowing in the European Union: From a pure national model to the antechamber of a 
European fiscal federal solution. Journal of European Integration, 1-16. https://doi.org/10.1080/07036337.2021.1881499

Carayannis, E., Grigoroudis, E., Campbell, D., Meissner, D., \& Stamati, D. (2018). The ecosystem as helix: An exploratory theory-building study of regional co-opetitive entrepreneurial ecosystems as Quadruple/Quintuple Helix Innovation Models. $R \& D$ Management, 48(1), 148-162. https://doi.org/10.1111/radm.12300

Chatzinikolaou, D., \& Vlados, Ch. (2019). Schumpeter, neo-Schumpeterianism, and Stra.Tech.Man evolution of the firm. Issues in Economics and Business (International Economics and Business), 5(2), 80-102. https://doi.org/10.5296/ieb.v5i2.16097

Chaves-Maza, M., \& Martel, E. M. F. (2020). Entrepreneurship support ways after the COVID-19 crisis. Entrepreneurship and Sustainability Issues, 8(2), 662-681. https://doi.org/10.9770/jesi.2020.8.2(40)

Council of the European Union. (2017). A renewed EU industrial policy strategy: Council adopts conclusions [Press release, $\quad 30 \quad$ November]. $\quad$ Retrieved from https://www.consilium.europa.eu/en/press/press-releases/2017/11/30/a-renewed-eu-industrial-policy-strategy-coun cil-adopts-conclusions

Cross, M. K. D. (2007). An EU homeland security? Sovereignty vs. supranational order. European Security, 16(1), 79-97. https://doi.org/10.1080/09662830701442410

Crum, B. (2020). How to provide political guidance to the Recovery and Resilience Facility? European Parliament. https://doi.org/10.2861/108171

Crumpton, M. A., \& Bird, N. J. (2019). Educating the entrepreneurial librarian. In J. Crum \& S. Hines (Eds.), Supporting entrepreneurship and innovation (Vol. 40, pp. 169-182). https://doi.org/10.1108/S0732-067120190000040011

De Cruz, P. (1999). Comparative law in a changing world. London: Cavendish.

Decreux, Y., \& Guérin, J.-L. (2001). Mercosur: Free-trade area with the EU or with the Americas? Some lessons from the model Mirage. Conference on Impacts of Trade Liberalization Agreements on Latin America and the Caribbean, Inter-American Development Bank, Washington DC, 5-6 November 2001.

Dodds, K., Broto, V. C., Detterbeck, K., Jones, M., Mamadouh, V., Ramutsindela, M., ... Woon, C. Y. (2020). The COVID-19 pandemic: Territorial, political and governance dimensions of the crisis. Territory, Politics, Governance, 8(3), 289-298. https://doi.org/10.1080/21622671.2020.1771022

Dopfer, K. (2011). The origins of meso economics: Schumpeter's legacy and beyond. Journal of Evolutionary Economics, 22(1), 133-160. https://doi.org/10.1007/s00191-011-0218-4

Dovers, S. R. (1995). A framework for scaling and framing policy problems in sustainability. Ecological Economics, 12(2), 93-106. https://doi.org/10.1016/0921-8009(94)00042-T

Draper, P. (2012). Breaking free from Europe: Why Africa needs another model of regional integration. The International Spectator, 47(1), 67-82. https://doi.org/10.1080/03932729.2012.655008

Dupont, C., Oberthür, S., \& von Homeyer, I. (2020). The Covid-19 crisis: A critical juncture for EU climate policy development? Journal of European Integration, 42(8), 1095-1110. https://doi.org/10.1080/07036337.2020.1853117

Elsner, W. (2017). Complexity economics as heterodoxy: Theory and policy. Journal of Economic Issues, 51(4), 939-978. https://doi.org/10.1080/00213624.2017.1391570

Epifanova, T. V., Kurinova, Y. I., \& Tertishnikova, M. P. (2020). Development of regional business ecosystems as an effective tool to counter the COVID-19 crisis. International Journal of Economics \& Business Administration (IJEBA), 8(4), 807-818. https://doi.org/10.35808/ijeba/630

Etemad, H. (2017). Towards an emerging evolutionary life-cycle theory of internationalized entrepreneurial firms: From born globals to borderless firms? Journal of International Entrepreneurship, 15(2), 111-120. https://doi.org/10.1007/s10843-017-0204-5

European Central Bank. (2020). ECB staff macroeconomic projections for the euro area, March 2020. European Central Bank.

Retrieved from https://www.ecb.europa.eu/pub/projections/html/ecb.projections202003_ecbstaff $\sim$ dfa19e18c4.en.html

European Commission. (2012). Guide to Research and Innovation Strategies for Smart Specialisation (RIS3). European Commission. 
https://ec.europa.eu/regional_policy/sources/docgener/presenta/smart_specialisation/smart_ris3_2012.pdf

European Commission. (2013). Entrepreneurship 2020 Action Plan: Reigniting the entrepreneurial spirit in Europe. European Commission. Retrieved from https://eur-lex.europa.eu/legal-content/EN/TXT/PDF/?uri=CELEX:52012DC0795\&from=EL

European Commission. (2014). Regional Implementation of the SBA. Publications Office of the European Union. Retrieved from https://op.europa.eu/en/publication-detail/-/publication/cfb47ae4-abcf-4a18-8058-177976f15647/language-en

European Commission. (2017a). Industry in Europe: Facts \& figures on competitiveness \& innovation 2017. Publications Office of the European Union. Retrieved https://op.europa.eu/en/publication-detail/-/publication/354c1e8b-1db0-11e7-aeb3-01aa75ed71a1/language-en

European Commission. (2017b). Strengthening innovation in Europe's regions: Strategies for resilient, inclusive and sustainable growth. European Commission. Retrieved from https://ec.europa.eu/regional_policy/en/information/publications/communications/2017/strengthening-innovation-i n-europe-s-regions-strategies-for-resilient-inclusive-and-sustainable-growth

European Council. (2020). Special Meeting of the European Council (1 and 2 October 2020) - Conclusions. Note from General Secretariat of the Council to Delegations. Retrieved from https://www.consilium.europa.eu/media/45910/021020-euco-final-conclusions.pdf

Falck, O., Gollier, C., \& Woessmann, L. (2011). Industrial policy for national champions. Cambridge: MIT Press. https://doi.org/10.7551/mitpress/9780262016018.001.0001

Falck, O., Heblich, S., \& Kipar, S. (2010). Industrial innovation: Direct evidence from a cluster-oriented policy. Regional Science and Urban Economics, 40(6), 574-582. https://doi.org/10.1016/j.regsciurbeco.2010.03.007

Food and Agriculture Organization (2020). COVID-19 and rural poverty: Supporting and protecting the rural poor in times of pandemic. Food and Agriculture Organization of the United Nations. Retrieved from http://www.fao.org/3/ca8824en/CA8824EN.pdf

Foray, D. (2018). Smart specialisation strategies and industrial modernisation in European regions-Theory and practice. Cambridge Journal of Economics, 42(6), 1505-1520. https://doi.org/10.1093/cje/bey022

Foray, D., David, P. A., \& Hall, B. (2009). Smart specialization: The concept. In Knowledge for growth: Prospects for science, technology and innovation: Selected papers from Research Commissioner Janez Potočnik's expert group (pp. 20-24). Luxembourg: Publications Office of the European Union.

Fotopoulos, G., \& Storey, D. J. (2019). Public policies to enhance regional entrepreneurship: Another programme failing to deliver? Small Business Economics, 53(1), 189-209. https://doi.org/10.1007/s11187-018-0021-9

Galbraith, J. K. (1987). Economics in perspective: A critical history. Boston: Houghton Mifflin.

Gilson, L. L., \& Goldberg, C. B. (2015). Editors' comment: So, what is a conceptual paper? Group \& Organization Management, 40(2), 127-130. https://doi.org/10.1177/1059601115576425

Godlewska-Majkowska, H., Komor, A., \& Typa, M. (2016). Special Economic Zones as growth and anti-growth poles as exemplified by Polish regions. Entrepreneurial Business and Economics Review, 4(4), 189-212. https://doi.org/10.15678/EBER.2016.040412

Gómez-Pineda, J. G. (2020). Growth forecasts and the Covid-19 recession they convey. Covid Economics, Vetted and Real-Time Papers, 40, $\quad$ Retrieved from https://www.researchgate.net/profile/Ioannis-Laliotis/publication/343307261_CovidEconomics40/links/5f22b3e1a 6fdcccc43995642/CovidEconomics40.pdf\#page=201

Gong, H., Hassink, R., Tan, J., \& Huang, D. (2020). Regional resilience in times of a pandemic crisis: The case of COVID-19 in China. Tijdschrift Voor Economische En Sociale Geografie, 111(3), $497-512$. https://doi.org/10.1111/tesg.12447

Gregory, V., Menzio, G., \& Wiczer, D. G. (2020). Pandemic Recession: L or V-Shaped? (No. w27105). National Bureau of Economic Research. https://doi.org/10.3386/w27105

Grimaccia, E. (2020). An analysis of the performance of European Union countries in the light of Europe 2020 strategy indicators. Review of European Studies, 12(4), 12-19. https://doi.org/10.5539/res.v12n4p12

Hartwell, C. A. (2014). Capital controls and the determinants of entrepreneurship. Czech Journal of Economics and Finance (Finance a Uver), 64(6), 434-456. 
http://journal.fsv.cuni.cz/storage/1310_434-456---hartwell.pdf

Hemphill, T. A., \& White, G. O. (2013). China's National Champions: The Evolution of a National Industrial Policy-Or a New Era of Economic Protectionism? Thunderbird International Business Review, 55(2), 193-212. https://doi.org/10.1002/tie.21535

Henry, N., \& Smith, A. (2021). Europe and/or the UK: Post-Brexit urban and regional development futures - A special issue. European Urban and Regional Studies, 28(1), 3-7. https://doi.org/10.1177/0969776420982742

Howlett, M. (2009). Governance modes, policy regimes and operational plans: A multi-level nested model of policy instrument choice and policy design. Policy Sciences, 42(1), 73-89. https://doi.org/10.1007/s11077-009-9079-1

Ignatov, A. (2018). Entrepreneurial innovation: The European Union perspective. Review of Economic Perspectives, 18(2), 137-154. https://doi.org/10.2478/revecp-2018-0008

Information Resources Management Association. (2019). Social entrepreneurship: Concepts, methodologies, tools, and applications. https://doi.org/10.4018/978-1-5225-8182-6

International Civil Aviation Organization. (2020, November 12). Effects of novel coronavirus (COVID-19) on civil aviation: Economic impact analysis. Air Transport Bureau Retrieved from https://www.aaco.org/Library/Files/Uploaded\%20Files/Economics/Corona\%20studies/3dec\%20ICAO_Coronaviru s_Econ_Impact.pdf

International Energy Agency. (2020). World energy outlook 2020 [Part of World Energy Outlook]. International Energy Agency. Retrieved from https://www.iea.org/reports/world-energy-outlook-2020

International Labour Organization. (2020). ILO Monitor: COVID-19 and the world of work. Fifth edition. International Labour Organization. Retrieved from https://www.ilo.org/wcmsp5/groups/public/---dgreports/---dcomm/documents/briefingnote/wcms_749399.pdf

International Monetary Fund. (2020). A crisis like no other, an uncertain recovery (World Economic Outlook Reports, World Economic Outlook Update, June 2020). Retrieved from https://www.imf.org/en/Publications/WEO/Issues/2020/06/24/WEOUpdateJune2020

Islam, N., McClelland, D. A., Charest, C., Harris, D. J., \& Genné, M. (1992). Growth, poverty and rural development: From trickle-down toward the great ascent-A review article. Canadian Journal of Development Studies / Revue Canadienne d'études Du Développement, 13(3), 443-462. https://doi.org/10.1080/02255189.1992.9669472

Jaakkola, E. (2020). Designing conceptual articles: Four approaches. AMS Review, 10(1), 18-26. https://doi.org/10.1007/s13162-020-00161-0

Jetschke, A., \& Murray, P. (2012). Diffusing regional integration: The EU and Southeast Asia. West European Politics, 35(1), 174-191. https://doi.org/10.1080/01402382.2012.631320

Kalemli-Ozcan, S., Gourinchas, P.-O., Penciakova, V., \& Sander, N. (2020). COVID-19 and SME Failures. IMF Working Papers, 20(207). https://doi.org/10.5089/9781513557748.001

Karlsson, C., \& Silander, D. (2020). Implementing sustainable development goals in Europe: The role of political entrepreneurship. Cheltenham: Edward Elgar Publishing. https://doi.org/10.4337/9781789909975

Ketels, C., \& Porter, M. E. (2020). Rethinking the role of the EU in enhancing European competitiveness. Competitiveness Review: An International Business Journal, 31(2), 189-207. https://doi.org/10.1108/CR-08-2020-0100

Kochenov, D. (2008). EU enlargement and the failure of conditionality: Pre-accession conditionality in the fields of democracy and the rule of law. Alphen aan den Rijn: Wolters Kluwer Law \& Business. https://doi.org/10.5771/9783845212272-103

Kurtz, C. (2018). Are we ready for complexity? Journal on Policy and Complex Systems, 4(1), 135-154. https://doi.org/10.18278/jpcs.4.1.7

Larionova, M., \& Kirton, J. (2020). Global Governance After the COVID-19 Crisis. International Organisations Research Journal, 15(2), 7-23. https://doi.org/10.17323/1996-7845-2020-02-01

Lee, K. Y. (2011). From third world to first: Singapore and the Asian economic boom. New York: Harper Business.

Link, A. N. (2007). Public policy and entrepreneurship. In D. B. Audretsch, I. Grilo, \& A. Thurik (Eds.), Handbook of research on entrepreneurship policy (pp. 130-139). Cheltenham: Edward Elgar.

Lundström, A., \& Stevenson, L. (2005). Entrepreneurship policy: Theory and practice. New York: Springer. 
Malen, J. (2015). Motivating and enabling firm innovation effort: Integrating penrosian and behavioral theory perspectives on slack resources. Hitotsubashi Journal of Commerce and Management, 49(1), 37-54. Retrieved from www.jstor.org/stable/43697708

Mann, S. (Ed.). (2011). Sectors matter! Exploring mesoeconomics. New York: Springer. https://doi.org/10.1007/978-3-642-18126-9

Maritz, A., Perenyi, A., de Waal, G., \& Buck, C. (2020). Entrepreneurship as the unsung hero during the current COVID-19 economic crisis: Australian perspectives. Sustainability, 12(11), 4612. https://doi.org/10.3390/su12114612

Marra, A., Mazzocchitti, M., \& Sarra, A. (2018). Knowledge sharing and scientific cooperation in the design of research-based policies: The case of the circular economy. Journal of Cleaner Production, 194, 800-812. https://doi.org/10.1016/j.jclepro.2018.05.164

Mason, C., \& Hruskova, M. (2021). The impact of Covid-19 on entrepreneurial ecosystems. In P. McCann \& T. Vorley, Productivity and the pandemic (pp. 59-72). https://doi.org/10.4337/9781800374607.00011

Menu, S. (2012). The role of cluster policy on leadership: Evidence from two pôles de compétitivité. Environment and Planning C: Government and Policy, 30(5), 816-834. https://doi.org/10.1068/c1190

Metcalfe, A. S. (2010). Examining the trilateral networks of the triple helix: Intermediating organizations and $\begin{array}{lllll}\text { academy-industry-government } & \text { relations. } & \text { Critical } & \text { Sociology, } & 36(4),\end{array}$ https://doi.org/10.1177/0896920510365920

Meunier, S., \& Mickus, J. (2020). Sizing up the competition: Explaining reform of European Union competition policy in the Covid-19 era. Journal of European Integration, 42(8), 1077-1094. https://doi.org/10.1080/07036337.2020.1852232

Meyer-Stamer, J. (2005). Systemic competitiveness revisited: Conclusions for technical assistance in private sector development [Mesopartner Working Paper 14]. Retrieved from https://www.mesopartner.com/fileadmin/media_center/Working_papers/mp-wp14_01.pdf

Mirzanti, I. R., Simatupang, T. M., \& Larso, D. (2015). Entrepreneurship policy implementation model in Indonesia. International Journal of Entrepreneurship and Small Business, 26(4), 399-415. https://doi.org/10.1504/IJESB.2015.072765

Muller, P., Caliandro, C., Peycheva, V., Gagliardi, D., Marzocchi, C., Ramlogan, R., \& Cox, D. (2015). Annual report on european SMEs [EU DG Internal Market, Industry, Entrepreneurship and SMEs]. European Commission. Retrieved from https://ec.europa.eu/docsroom/documents/16341/attachments/2/translations/en/renditions/native

Nakwa, K., Zawdie, G., \& Intarakumnerd, P. (2012). Role of Intermediaries in Accelerating the Transformation of Inter-Firm Networks into Triple Helix Networks: A Case Study of SME-based Industries in Thailand. Procedia Social and Behavioral Sciences, 52, 52-61. https://doi.org/10.1016/j.sbspro.2012.09.441

Organisation for Economic Co-operation and Development. (2007). Micro-policies for growth and productivity Summary of key findings. Paris: Organisation for Economic Co-operation and Development.

Organisation for Economic Co-operation and Development. (2009). Competition policy, industrial policy and national champions. Roundtable on Competition Policy, Industrial Policy and National Champions. Global Forum on Competition. Retrieved from https://www.oecd.org/daf/competition/44548025.pdf

Organisation for Economic Co-operation and Development. (2020a). Coronavirus (COVID-19): SME policy responses (Updated July 15th, 2020). Retrieved from https://read.oecd-ilibrary.org/view/?ref=119_119680-di6h3qgi4x\&title=Covid-19_SME_Policy_Responses

Organisation for Economic Co-operation and Development. (2020b). OECD economic outlook, Volume 2020 Issue 2. Paris: Organisation for Economic Co-operation and Development.

Organisation for Economic Co-operation and Development. (2020c). E-commerce in the time of COVID-19 (Tackling Coronavirus (COVID-19): Contributing to a Global Effort). Secretary-General of the Organisation for Economic Co-operation and Development. Retrieved from http://www.oecd.org/coronavirus/policy-responses/e-commerce-in-the-time-of-covid-19-3a2b78e8/

Parr, J. B. (1999). Growth-pole strategies in regional economic planning: A retrospective view: Part 1. Origins and advocacy. Urban Studies, 36(7), 1195-1215. https://doi.org/10.1080/0042098993187

Paché, G. (2020). The "day after” Covid-19 pandemic: Logistical disorders in perspective. Review of European Studies, 


\section{2(3), 1-8. https://doi.org/10.5539/res.v12n3p1}

Pelkmans, J. (1993). Comparando las integraciones económicas: Prerequisitos, opciones e implicaciones [Comparing economic integrations: Prerequisites, options and implications ]. Integración Latinoamericana, 191, 3-17.

Peneder, M. (2017). Competitiveness and industrial policy: From rationalities of failure towards the ability to evolve. Cambridge Journal of Economics, 41(3), 829-858. https://doi.org/10.1093/cje/bew025

Phelan, W. (2012). What is sui generis about the European Union? Costly international cooperation in a self-contained regime. International Studies Review, 14(3), 367-385. https://doi.org/10.1111/j.1468-2486.2012.01136.x

Pike, A., Rodríguez-Pose, A., \& Tomaney, J. (2012). Handbook of local and regional development. London: Routledge. Retrieved from http://www.credoreference.com/book/routlrd

Podkaminer, L. (2019). Is better economic integration in the EU possible? European Journal of Economics and Economic Policies: Intervention, 16(3), 370-380. https://doi.org/10.4337/ejeep.2019.0054

Porte, C. de la, \& Jensen, M. D. (2021). The next generation EU: An analysis of the dimensions of conflict behind the deal. Social Policy \& Administration, 1-15. https://doi.org/10.1111/spol.12709

Porter, M. (1990). The competitive advantage of nations (First Free Press Edition 1990). New York: Free Press. https://doi.org/10.1007/978-1-349-11336-1

Reimann, M., \& Zimmermann, R. (2019). The Oxford handbook of comparative law. Oxford: Oxford University Press. https://doi.org/10.1093/oxfordhb/9780198810230.001.0001

Rinkinen, S. (2016). Clusters, Innovation Systems and Ecosystems: Studies on innovation policy's concept evolution and approaches for regional renewal [Lappeenranta University of Technology]. Retrieved from http://urn.fi/URN:ISBN:978-952-335-035-9

Rodrigues, C., \& Melo, A. (2012). The Triple Helix Model as an Instrument of Local Response to the Economic Crisis. European Planning Studies, 20(9), 1483-1496. https://doi.org/10.1080/09654313.2012.709063

Rodríguez-Cohard, J. C., Juste-Carrión, J. J., \& Vásquez-Barquero, A. (2020). Local development policies: Challenges for post-COVID-19 recovering in Spain. Symphonya. Emerging Issues in Management, (2), 41-54. https://doi.org/10.4468/2020.2.05rodriguez.juste.vazquez

Roper, S., \& Turner, J. (2020). R\&D and innovation after COVID-19: What can we expect? A review of prior research and data trends after the great financial crisis. International Small Business Journal, 38(6), 504-514. https://doi.org/10.1177/0266242620947946

Ruiu, M. L. (2020). Mismanagement of Covid-19: Lessons learned from Italy. Journal of Risk Research, 23(7-8), 1007-1020. https://doi.org/10.1080/13669877.2020.1758755

Sá, E., Casais, B., \& Silva, J. (2018). Local development through rural entrepreneurship, from the triple helix perspective: The case of a peripheral region in Northern Portugal. International Journal of Entrepreneurial Behavior \& Research, 21(1), 5-26. https://doi.org/10.1108/IJEBR-03-2018-0172

Schäfer, M. (2018). The fourth industrial revolution: How the EU can lead it. European View, 17(1), 5-12. https://doi.org/10.1177/1781685818762890

Schalck, C. (2012). Investigating heterogeneity in European fiscal behaviours. Research in Economics, 66(4), 383-390. https://doi.org/10.1016/j.rie.2012.06.002

Scholta, H., Mertens, W., Kowalkiewicz, M., \& Becker, J. (2019). From one-stop shop to no-stop shop: An e-government stage model. Government Information Quarterly, 36(1), 11-26. https://doi.org/10.1016/j.giq.2018.11.010

Schumpeter, J. (1942). Capitalism, socialism and democracy (Edition published in the Taylor\&Francis e-Library, 2003). New York: Harper \& Brothers.

Schumpeter, J. (1954). History of economic analysis (Edition published in the Taylor\&Francis e-Library, 2006). Oxford: Oxford University Press.

Sedelmeier, U. (2002). Sectoral dynamics of EU enlargement: Advocacy, access and alliances in a composite policy. Journal of European Public Policy, 9(4), 627-649. https://doi.org/10.1080/13501760210152466

Shepherd, D. A. (2020). COVID 19 and Entrepreneurship: Time to pivot? Journal of Management Studies, 57(8), 1750-1753. https://doi.org/10.1111/joms. 12633

Snyder, H. (2019). Literature review as a research methodology: An overview and guidelines. Journal of Business 
Research, 104, 333-339. https://doi.org/10.1016/j.jbusres.2019.07.039

Sowell, T. (2012). Trickle down theory and tax cuts for the rich. Stanford (California): Hoover Institution Press.

Stockhammer, E. (2017). Post-Keynesian economics. In L. Fischer, J. Hasell, J. C. Proctor, D. Uwakwe, Z. Ward-Perkins, \& C. Watson (Eds.), Rethinking Economics: An introduction to pluralist economics (pp. 6-18). https://doi.org/10.4324/9781315407265

Terjesen, S. (2021). Entrepreneurial finance: Research, practice, and policy for post-Covid-19 economic recovery. Journal of Risk and Financial Management, 14(1), 18. https://doi.org/10.3390/jrfm14010018

Timmer, C. P. (2000). The macro dimensions of food security: Economic growth, equitable distribution, and food price stability. Food Policy, 25(3), 283-295. https://doi.org/10.1016/S0306-9192(00)00007-5

Umar, M., Rizvi, S. K. A., \& Naqvi, B. (2021). Dance with the devil? The nexus of fourth industrial revolution, technological financial products and volatility spillovers in global financial system. Technological Forecasting and Social Change, 163, 120450. https://doi.org/10.1016/j.techfore.2020.120450

United Nations. (2020). Global humanitarian response plan: COVID-19 (United Nations coordinated appeal: April-December 2020). Retrieved from https://www.unocha.org/sites/unocha/files/Global-Humanitarian-Response-Plan-COVID-19.pdf

Uyarra, E., \& Flanagan, K. (2010). From regional systems of innovation to regions as innovation policy spaces. Environment and Planning C: Government and Policy, 28(4), 681-695. https://doi.org/10.1068/c0961

Virtanen, P., \& Uusikylä, P. (2004). Exploring the missing links between cause and effect: A conceptual framework for understanding micro-macro conversions in programme evaluation. Evaluation, 10(1), 77-91. https://doi.org/10.1177/1356389004043136

Vlados, Ch. (2004). La dynamique du triangle stratégie, technologie et management: L'insertion des entreprises grecques dans la globalisation [The dynamics of the triangle of strategy, technology and management: The insertion of Greek enterprises into globalization] [Thèse de doctorat de Sciences Économiques, Université de Paris X-Nanterre]. Retrieved from http://www.theses.fr/2004PA100022

Vlados, Ch. (2019a). Change management and innovation in the "living organization": The Stra.Tech.Man approach. Management Dynamics in the Knowledge Economy, 7(2), 229-256. https://doi.org/10.25019/MDKE/7.2.06

Vlados, Ch. (2019b). Porter's diamond approaches and the competitiveness web. International Journal of Business Administration, 10(5), 33-52. https://doi.org/10.5430/ijba.v10n5p33

Vlados, Ch., \& Chatzinikolaou, D. (2019a). Business ecosystems policy in Stra.Tech.Man terms: The case of the Eastern Macedonia and Thrace region. Journal of Entrepreneurship, Management and Innovation, 15(3), $163-197$. https://doi.org/10.7341/20191536

Vlados, Ch., \& Chatzinikolaou, D. (2019b). Developments on helix theory: Exploring a micro-evolutionary repositioning in Stra.Tech.Man terms. International Journal of World Policy and Development Studies, 5(10), 87-99. https://doi.org/10.32861/ijwpds.510.87.99

Vlados, Ch., \& Chatzinikolaou, D. (2020a). From growth poles and clusters to business ecosystems dynamics: The ILDI counterproposal. International Journal of World Policy and Development Studies, 6(7), 115-126. https://doi.org/10.32861/ijwpds.67.115.126

Vlados, Ch., \& Chatzinikolaou, D. (2020b). Macro, meso, and micro policies for strengthening entrepreneurship: Towards an integrated competitiveness policy. Journal of Business \& Economic Policy, 7(1), 1-12. https://doi.org/10.30845/jbep.v7n1a1

Vlados, Ch., \& Chatzinikolaou, D. (2020c). Thoughts on competitiveness and integrated industrial policy: A field of mutual convergences. Research in World Economy, 11(3), 12-25. https://doi.org/10.5430/rwe.v11n3p12

Vlados, Ch., Chatzinikolaou, D., Katimertzopoulos, F., \& Koutroukis, T. (2019). Regional underdevelopment and less developed business ecosystems: The case of Eastern Macedonia and Thrace. Bulletin of Applied Economics, 6(2), $31-44$.

Vlados, Ch., Deniozos, N., \& Chatzinikolaou, D. (2018a). Towards a new approach of local development under crisis conditions: Empowering the local business ecosystems in Greece, by adopting a new local development policy. International Journal of Regional Development, 5(1), 1-24. https://doi.org/10.5296/ijrd.v5i1.11955

Vlados, Ch., Deniozos, N., Chatzinikolaou, D., \& Demertzis, M. (2018b). Towards an evolutionary understanding of the current global socio-economic crisis and restructuring: From a conjunctural to a structural and evolutionary 
perspective. Research in World Economy, 9(1), 15-33. https://doi.org/10.5430/rwe.v9n1p15

Vlados, Ch., \& Katimertzopoulos, F. (2018). Assessing meso and micro-competitiveness boosting policies, in Stra.Tech.Man terms. International Journal of Business and Social Research, 8(9), 1-15. https://doi.org/10.5296/jebi.v5i2.13477

Warwick, K. (2013). Beyond industrial policy: Emerging issues and new trends (OECD Science, Technology and Industry Policy Papers No. 2). https://doi.org/10.1787/5k4869clw0xp-en

Watkins, J. P. (2014). Quantitative easing as a means of reducing unemployment: A new version of trickle-down economics. Journal of Economic Issues, 48(2), 431-440. https://doi.org/10.2753/JEI0021-3624480217

Weresa, M. A. (2019). Technological competitiveness of the EU member states in the era of the fourth industrial revolution. Economics and Business Review, 5(3), 50-71. https://doi.org/10.18559/ebr.2019.3.4

Winarsih, Indriastuti, M., \& Fuad, K. (2021). Impact of Covid-19 on digital transformation and sustainability in Small and Medium Enterprises (SMEs): A conceptual framework. In L. Barolli, A. Poniszewska-Maranda, \& T. Enokido (Eds.), Complex, intelligent and software intensive systems (pp. 471-476). https://doi.org/10.1007/978-3-030-50454-0_48

World Bank. (2020). Global economic prospects. https://doi.org/10.1596/978-1-4648-1553-9

World Health Organization. (2020). WHO Director-General's opening remarks at the media briefing on COVID-19-23 July 2020. from https://www.who.int/director-general/speeches/detail/who-director-general-s-opening-remarks-at-the-media-briefin g-on-covid-19---23-july-2020

Yvars, B. (2010). EU integration and other integration models. In F. Bindi (Ed.), The foreign policy of the European Union: Assessing Europe's role in the world (pp. 273-289). Washington, DC: Brookings Institution Press.

Zahra, S. A. (2021). International entrepreneurship in the post Covid world. Journal of World Business, $56(1), 101143$. https://doi.org/10.1016/j.jwb.2020.101143

Zezza, A., \& Llambí, L. (2002). Meso-economic filters along the policy chain: Understanding the links between policy reforms and rural poverty in Latin America. World Development, 30(11), 1865-1884. https://doi.org/10.1016/S0305-750X(02)00113-4

\section{Copyrights}

Copyright for this article is retained by the author(s), with first publication rights granted to the journal.

This is an open-access article distributed under the terms and conditions of the Creative Commons Attribution license (http://creativecommons.org/licenses/by/4.0/). 